\title{
THE RELATIONSHIP BETWEEN GREEN HUMAN RESOURCE MANAGEMENT AND GREEN SUPPLY CHAIN MANAGEMENT
}

\author{
Nurten POLAT DEDE ${ }^{1}$
}

\begin{abstract}
Recently, the results of green human resource management (GHRM) and green supply chain management (GSCM) practices of companies such as environmental protection, sustainable development and gaining competitive advantage are widely discussed in the literature. As the activities of the companies to increase their ecological performance within the scope of sustainability become widespread in all sectors, it is seen that some companies begin to play important roles in supply chain processes by designing HRM practices, which are referred to as the best green human resource management practices. This study seeks to answer the questions of (i) what are the main components of GHRM and GSCM applications and (ii) which HRM and SCM applications produce effective results in terms of firms' ecological performance in ensuring GHRM and GSCM integration. In this respect, the study consists of two main parts. In the first part of the study, a conceptual model explaining the effects of GSCM and GHRM on the ecological performance of firms as a result of their separate and joint interactions is proposed for the first time in the national literature. In the second part of the study, research conducted with senior supply chain unit managers and HRM directors of leading companies in the sector with their environmentally sensitive practices. The research was conducted with an in-depth interview method, which is one of the qualitative data collection methods. As a result of the analyzes, significant differences were found between GSCM and GHRM relations between supply chain unit managers and HRM unit managers. Besides, the level and commitment of the senior management and other department managers to adopt environmental values were determined by all participants as the most important human factor in determining the effectiveness of GHRM and GSCM practices.
\end{abstract}

Keywords: Human Resource Management, Supply Chain Management, Sustainability, Green Human Resource Management, Green Supply Chain Management.

JEL Classification: M10, M12, M54, L91, Q56.

\section{YEŞIL INSAN KAYNAKLARI YÖNETIMI VE YEŞIL TEDARIKK ZINCIRİ YÖNETIMII ARASINDAKİ İLIŞKILER}

\section{$\ddot{O} \mathbf{z}$}

Son dönemde, firmaların yeşil insan kaynakları yönetimi (YİKY) ve yeşil tedarik zinciri yönetimi (YTZY) uygulamalarının; çevre koruma, sürdürülebilir kalkınma ve rekabet avantajı elde etme gibi sonuçları, literatürde yaygın olarak tartışılmaktadır. Firmaların, sürdürülebilirlik kapsamındaki ekolojik performanslarını artırmaya yönelik faaliyetleri tüm sektörlerde yaygınlaştıkça, bazı firmaların insan kaynakları departmanlarının da en iyi yeşil insan kaynakları yönetimi uygulamaları olarak ifade edilen İKY uygulamalarını tasarlayarak, şirketlerinin tedarik zinciri süreçlerinde roller üstlenmeye başladıkları görülmektedir.

Bu çalışmada (i) YİKY ve YTZY uygulamalarının temel bileşenlerinin neler olduğu ve (ii) YİKY ve YTZY entegrasyonunun sağlanmasında hangi İKY ve TZY uygulamalarının firmaların ekolojik performansı açısından etkili sonuçlar ürettiği sorularına yanıt aranmaktadır. Bu doğrultuda çalışma iki temel bölümden oluşmaktadır.

1 Asst. Prof. Nurten POLAT DEDE, Medipol University, Medipol Business School, Istanbul, Turkey, ndede@medipol.edu.tr, ORCID: 0000-0002-9952-4642 
Çalışmanın ilk bölümünde YTZY ve YİKY'nin birbirinden ayrı olarak ve birlikte etkileşimleri sonucunda firmaların ekolojik performanslarına olan etkilerini açılayan kavramsal bir model ulusal literatürde ilk kez önerilmektedir.

Çalışmanın ikinci bölümünde ise; çevreye duyarlı uygulamaları ile sektörde öncü olan holdinglerin tedarik zinciri üzerinde yer alan üst düzey birim yöneticileri ve İKY direktörleri ile gerçekleştirilen bir araştırma yer almaktadır. Araştırma nitel bilgi toplama yöntemlerinden biri olan, derinlemesine görüşme yöntemi ile gerçekleştirilmiştir. Yapılan analizler sonucunda, YTZY ve YİKY ilişkilerinde birim yöneticileri ve İKY birim yöneticileri görüşleri arasında önemli farklılıklar saptanmıştır. Bununla birlikte tüm katılımcılarca, üst yönetimin ve diğer bölüm yöneticilerinin çevreci değerleri benimseme düzeyleri ve taahhütleri, YİKY ve YTZY uygulamalarının etkinliğini belirlenmesinde, en önemli beşeri unsur olarak tespit edilmiştir.

Anahtar Kelimeler: İnsan Kaynakları Yönetimi, Tedarik Zinciri Yönetimi, Sürdürülebilirlik, Yeşil İnsan Kaynakları Yönetimi, Yeşil Tedarik Zinciri Yönetimi.

JEL Sinıflaması: M10, M12, M54, L91, Q56.

\section{Introduction}

In recent years, sustainability efforts have been one of the most powerful weapons in the wars of companies to improve and protect their public image. Today, companies need different management systems for reasons such as sectoral and organizational factors, costs of logistics activities (Nikbakhsh, 2009), legal regulations, orientation to social responsibility activities (Sari, 2017) and meeting customer needs (Srivastava, 2007). These systems; supply chain management, environmental management, human resources management and sustainability. These applications are put into practice in companies and they are brought together to produce more than the value they will produce alone.

Recently, companies have invested heavily in establishing, developing and integrating supply chain management (SCM), environmental management (EM) and human resource management (HRM) systems. In particular, the tendency of customers to choose environmentally-friendly products has made the suppliers' social and environmental practices an important criterion in supplier selection of companies (Ahi \& Searcy, 2013; Gold, Seuring \& Beske, 2010).

Coordination and cooperation of the supply chain is the most critical success factor with globalization. The supply chain is also expressed as a network forming the purchase options of raw materials, the production of intermediate goods or final products, the distribution of finished products to customers and the distribution options (Ganeshan \& Harrison, 1995: 1).

Supply chain management (SCM), is defined as a series of approaches used to integrate suppliers, manufacturers, wholesalers and retailers to meet the needs of stakeholders while minimizing costs across the supply chain system so that the products are produced and distributed in the right place, at the right time, in the right amount.

To meet the demands of the customers in the most accurate and fastest way, these are the systems that handle suppliers, manufacturers, distributors and customers in an integrated way by using information technologies (Vonderembse, Uppal, Huang \& Dismukes, 2006).

Environmental management is a form of management that takes into account the harm that it may cause to the environment in the design, production, packaging and distribution activities of the companies in its high-level management decisions and minimizes these damages with the necessary measures and performs them within the scope of social responsibility practices (Chan, 2009; Cramer, 1998). 
Green supply chain (GSC) is a type of supply chain where strategies to produce environmentally responsible products or services are combined (Cruz \& Matsypura, 2009; Sarkis, 2012). It reduces the negative environmental impacts of companies and increases their efficiency, giving them a competitive advantage over their competitors in innovation and processes (Thürer, Godinho Filho, Stevenson \& Fredendall, 2013).

Green supply chain management (GSCM) is a form of management obtained by applying environmental management principles to supply chain management. Being an integrated system, green supply chain management is acknowledged by both academics and executives that each system contributes more than the contribution it can make individually (Jabbour \& De Sousa Jabbour, 2016). Today, green supply chain management has reached a strategic position for companies in supply chains as a sub-dimension of sustainable supply chain management philosophy with covering environmental awareness and gaining a certain development.

Kopicki, Berg and Legg (1993), classify the approaches of companies in environmental management in three ways, the first of which is reactive. Companies with a reactive approach in environmental management implement practices for the purchase of recyclable raw materials or semi-finished products for production, filtration of the carbon footprint that harms the environment during the production stage, and the use of recyclable labels for manufactured products. Financial resources allocated to environmental activities are at a low level and the aim is to fulfill the laws. Companies that have adopted a proactive approach; take precautions before environmental problems occur. However, these practices are not combined with the company's business strategies. The last approach is expressed as a value-creating approach (Van Hoek, 1999). Business strategies are the motivation of the companies that adopt this approach towards voluntary environmental management. It is used by companies that have adopted a customer focus and differentiation strategy (Tatoglu, Frynas, Bayraktar, Demirbag, Sahadev, Doh \& Koh, 2019). Senior Management has a strong environmental commitment to green environmental management activities and the environmental commitment is shared among the supply chain partners. At the value creation stage, operating systems develop a redesign of products for assembly, conduct environmental analyzes at all stages of the product life cycle, and develop collaborations with other chain members (Van Hoek, 1999). GSCM is a strategic subject in these companies.

Another critical issue in today's conditions, as well as the supply chain management performance of enterprises, is to increase the strategic contribution of human resources. The concept of strategic human resources management (SHRM) was introduced in the early 1980s and developed. The association of HRM policies and practices with organizational goals and strategies has brought the concept to the agenda.

Snell, Youndt and Wright (1996), defined strategic human resource management as the design of HRM systems to achieve sustainable competitive advantage through people. The subject of SHRM is to investigate which strategic choices are made regarding the use of labor in firms and why some companies manage human resources more effectively than others (Boxall \& Purcell, 2000: 185).

Green human resources management (GHRM), on the other hand, is a new topic in the literature as a result of the widespread sustainability activities of companies. Some researchers have tried to draw attention to GHRM (Mandip, 2012; Renwick, Redman \& Maguire, 2013). 
GHRM consists of efforts to develop the best green HRM application sets for minimizing or eliminating the damages that may be caused by the activities of the companies in all business processes (Zaid, Bon \& Jaaron, 2018).

In general, researchers working in the field of business focus on the core issues of SCM such as purchasing, production and distribution, while they do not work on HRM, one of the soft elements. It is believed that researchers working on HRM are not interested in the literature on SCM. Human resources management departments in enterprises are not directly responsible for supply chain management, product development, process development, technology development, purchasing, distribution, recycling. However, HRM can positively or negatively influence the company's SCM and GSCM performance, either as an organizer or as a practitioner of organizational policies (Ellinger \& Ellinger, 2014; Gowen III \& Tallon, 2003; Lengnick-Hall, Lengnick-Hall \& Rigsbee, 2013; McAfee, Glassman \& Honeycutt, 2002).

Strategically, SCM makes significant contributions to resources and capabilities such as information exchange and joint planning between companies in the chain, cooperation based on the needs of end-users, long-term working and trust between the parties, fair sharing of risks and gains, creating common vision and culture (Baki, 2004). Environmental management (EM) is defined as an important managerial capability that ensures the continuity of social and ethical responsibility (Arda, Tatoğlu \& Alpkan, 2018). HRM, on the other hand, supports the contributions of SCM and EM through human resources and capabilities in enterprises.

Within the scope of the research, it was found that the number of publications investigating the relations between GHRM and GSCM was negligible in the searches made in large databases such as Ulakbim, Scopus and ISI Web of Science database. In our country, a published study investigating the relationship between GHRM and GSCM was not found in searches in these databases. This result is not surprising given that the studies in the field of GHRM in the national literature are relatively at an early stage compared to the studies in the field of GSCM. In fact, internationally, the relations between GSCM and GHRM have started to be discussed with a long delay. Researchers working on GSCM until the last few years seem to prefer to focus on the technical aspects of the subject and ignore the human elements of the green supply chain.

In this study, it is aimed to explain the relations between the two fields by bringing together the GSCM and GHRM fields which progress independently in the national literature. It is also sought to answer the questions of (i) what are the main components of GHRM and GSCM applications and (ii) which HRM and SCM applications produce effective results in terms of firms' ecological performance in ensuring GHRM and GSCM integration.

In this respect, the study consists of three main parts. In the first part of the study, the concepts of sustainability, environmental management, supply chain management and human resources management are explained to provide the basis for the concepts and processes that will be examined in explaining the relations between GHRM, GSCM and companies' environmental performance.

In the second part of the study, the activities of green product design, green material management / manufacturing, green distribution / marketing and reverse logistics (Ghobakhloo, Tang, Zulkifli \& Ariffin, 2013), which form GSCM business processes, are explained by using the opinions of researchers working on GSCM. 
After explaining the concept of GSCM and its dimensions, GHRM concept is explained within the framework of green HRM implementation proposals that can be applied in GSCM systems and processes. The conceptual model explaining the effects of GSCM and GHRM on environmental performance separately and the contribution of GSCM and GHRM as a result of their interactions (GSCM * GHRM) for the first time in the national literature. In the model, the relationship between GHRM formed by EM and HRM and GSCM formed by EM and SCM will be studied. With the theoretical dimension of the study, it is aimed to provide holistic perspective that will enable them to increase their ecological sustainability performance to the literature and business professionals.

In the third part of the study, there is a qualitative research conducted with senior unit managers and HRM directors located on the supply chain of large-scale holding companies that have stated that GSCM and GHRM applications are included in their companies. Also, the purpose and importance of the research, the data collection method and sample of the research, the questions of the research, the validity and reliability of the research, the research findings and the discussion about the research findings are presented in this section.

In the conclusion section, the contributions, importance and limitations of the research for theoretical and practitioners are mentioned and suggestions are made for future research.

\section{Conceptual Background for Integration of GHRM and GSCM Systems}

In this part of the study, the concepts of sustainability, environmental management, supply chain management and human resources management will be explained first to provide the basis for the concepts and processes that will be examined in explaining GHRM and GSCM relations.

\subsection{Sustainability and Environmental Management}

Today, environmental protection and sustainable development are among the most important issues for all industries. Businesses have to accept these two concepts among their priorities, formulate their policies and programs accordingly, and establish an environmental management system appropriate to the structures of their businesses.

Sustainability, which is widely discussed, is expressed as a participatory process that creates a perspective in the society to ensure the continuity of the economic, environmental and social resources of the society and to maintain the most accurate use of these resources (Gladwin, Kennelly \& Krause, 1995). According to Daly and Cobb (1994), sustainability is to meet the current needs with available resources in a way that does not harm the needs of future generations.

Sustainability is used as sustainable development within the framework of questioning whether the will necessary for the economic and social development of the society is implemented correctly and adequately (Akgül, 2010: 135). The economic levels of institutions and their impact on national and global economic systems are related to the economic dimension of sustainability. The impacts of institutions on living and non-living natural systems, including ecosystem, soil, air and water, are related to the environmental dimension. The social dimension of sustainability is related to the impact an organization has on social systems in its environment (Global Reporting Initiative, 2006).

The first motivation for sustainable development studies in the literature is based on the report published by the Environment and Development Commission in 1987. 
According to this report, countries need to achieve their growth targets in a way to support environmental, social and economic development. Businesses began to implement environmental policies, particularly when governments made it necessary to control water and air-related wastes (Morrow \& Rondinelli, 2002). Non-governmental organizations, environmental awareness in the society, legal regulations and customers' expectations are shown as important reasons for enterprises to develop environmental policies.

According to the theory of institutionalization, one of the most important goals of firms is to achieve legitimacy by adapting to the society in which they are located (Meyer \& Rowan, 1977). Businesses are seen as responsible for most of the carbon emissions in the past and present. The main reason of the environmental management activities of the companies is to ensure the legitimacy and continuity of the society by adapting to the environment, society and culture. Therefore, companies continue to research on innovative technologies in order to minimize the effects of environmental damages by producing less harmful products to the environment (Hosain \& Rahman, 2016) and they allocate a significant portion of its resources to these studies, inform the society with the reports they have published and want to raise or protect their social image in relation to their impact on the environment. Besides, it is not enough that environmentally friendly products are produced, they are also expected to consider the environment in procurement, production, packaging, storage, distribution and recycling processes.

EM is a management system established by enterprises to develop a certain environmental policy in order to reduce the negative impacts on the environment and nature (Arda et al., 2018). The environmental management system provides developments of environmental protection systems and processes to ensure that environmental impacts are taken into consideration in operational decisions. Environmental management is not only for control purposes. It has the effect that companies fulfill their social responsibilities related to environment, reduce their risks and increase their market opportunities. According to Van Hoek (1999), environmental management activities not only reduce the environmental damage of companies but also increase their efficiency, create a competitive advantage through innovation and improvement of processes. Contrary to popular belief, environmental management is not an emerging management system.

Firms have been implementing environmental management systems for years to fulfill their legal responsibilities, to obtain information about the risks arising from the pollution or danger caused by the activities of the company, to increase production efficiency and to prevent the unnecessary expenditures (Tepedelen \& Özdemir, 2003).

Environmental management practices that companies have independently performed for years have been gathered under a single structure under the International Standards Organization (ISO) 14001 EMS User Guide Specifications. ISO 14001 Standard defines the basic elements of an effective environmental management system. These elements form a management system that includes the resources needed to develop, implement and review organizational structure, planning activities, responsibilities, procedures, processes and environmental policy (Epstein \& Roy, 1998). When the objectives and objectives of the Environmental Management System ISO 14001 are considered, the impacts of the companies on the environment are documentable and not only provide a good image but also contribute to the economy. 
In practice, there are environmental criteria and guidelines developed by non-profit organizations such as UN Global Compact, the Guide to Corporate Sustainability, UN Indicators of Sustainable Development, Global Reporting Initiative GRI, Dow Jones Sustainability Index, OECD Environmental Indicators, EPA Report on the Environment, EEA Indicators, European Environment Agency, Environmental Performance Index (EPI), ISO 14031 Environmental Performance Evaluation (EPE). Companies use different environmental performance indicators according to their operating characteristics, the sector they use or the reporting systems they use and the impact of their stakeholders. Different products and sectors can have different effects on the environment in the production and supply chain management processes. For example, one sector can cause more carbon dioxide emissions, while another sector can lead to more water consumption. This may lead to changes in sustainability indicators and importance levels by sector (Nakıboğlu \& Bulgurcu, 2017). The environmental performance indicators used by researchers working on green supply chain management were determined by Ahi and Searcy (2015) in their study. These indicators are shown in Table 1 below.

Table 1: Environmental Performance

\begin{tabular}{|l|c|}
\hline \multirow{1}{*}{ Environmental } & Total direct and indirect toxic emissions \\
\cline { 2 - 3 } & Air emission \\
\cline { 2 - 3 } & Total greenhouse gas emissions/ozone harmful gases \\
\cline { 2 - 3 } & Water use \\
\cline { 2 - 3 } & Total energy use \\
\cline { 2 - 3 } & Costs due to environmental issues \\
\cline { 2 - 3 } & Amount of waste water \\
\cline { 2 - 3 } & Amount of material recycled \\
\cline { 2 - 3 } & Carbon footprint calculations \\
\cline { 2 - 3 } & Green product design \\
\hline
\end{tabular}

\subsection{Supply Chain Management}

Modern transport and other technologies have led to the development of global trade. While these developments create opportunities for companies, they have brought some difficulties. It is becoming increasingly difficult to obtain clear information about the supply conditions of raw materials to companies in various parts of the world. While the traditional supply chain becomes more complex with globalization, environmental and social performances have become increasingly important as well as the economic benefits of the chain.

Supply chain management can be defined as the strategic realization of the flow, supply, shipment and storage of raw materials, semi-finished and finished products throughout the operating and distribution systems (Christopher, 1998). 
Integrated supply chain comprises; operations planning, procurement and purchasing, production, inventory management, storage, distribution, after-sales customer relations and recycling processes. Briefly, supply chain management covers all stages from the procurement of raw material to the final consumer (Bowersox, Closs, Cooper \& Bowersox, 2013).

Supply chain management includes supply and demand management, raw material procurement, production, storage, inventory management, order management, distribution and marketing activities and ensures the sustainability of these activities (Yüksel, 2004). There are three types of flows in the supply chain: material flow, information flow and financial flow. Material flow; consists of physical product flow from suppliers to customers, and a reverse flow of return, service, recycling and product disposal. In the flow; spare parts, raw materials and intermediate products come from suppliers and continuous flow is very important to keep customers. While the information flow includes order notification and shipment status information, the financial flow regulates the money flow in the chain (Christopher, 1998).

The rapidly changing environment of competition forces companies to respond to these challenges by establishing collaborative relationships with their customers and suppliers. In the classical supply chain, relationships are often price-based and competitive. Modern supply chain management is based on collaboration, problem-solving, and strategic integration of suppliers and distributors (Bowersox et al., 2013). The effectiveness of collaborative supplier relationships depends on building trust among the firms in the chain.

\subsection{Human Resource Management}

The first reference to the concept of human resources management was made by Miles in 1965 . It expresses a people-oriented understanding focused on the needs, training and development of individuals working in enterprises, (Truss, Gratton, Hope-Hailey, McGovern \& Stiles, 1997). In the historical development of human resources, it is seen that three basic phases are experienced: personnel management, HRM and strategic HRM. The roles played by the HR manager vary at each stage. The differentiating structure of manpower, changes in the organization of the work and the forms of employment (depreciation of the concept of time and space in terms of labor force) and the increasing importance of the "human" element in the success of enterprises brought about a significant change in HR policies and practices (Yüksel, 1997: 33).

Nowadays, being able to direct human and intellectual capital in line with business objectives constitutes the most important competitive advantage of companies (Polat Dede, 2018). HRM departments can influence employee competencies, organizational citizenship behaviors (Sun, Aryee \& Law, 2007), organizational commitment (El-Kassar \& Singh, 2019), organizational participation and motivation (Mcmeekin \& Coombs, 1999) and contribute their organizational strategies through practices and policies they develop (Boxall \& Purcell, 2000).

There are two basic approaches in defining the strategies of human resources management departments. These approaches are expressed as reactive and proactive approaches.

In the reactive approach, organizational strategy forms the basis for HRM management strategies and policies. In this approach; HR practices such as performance appraisal, employment, training and remuneration make significant contributions to executives in the implementation of organizational strategic plans. 
In the proactive approach, it is seen that human resources departments have more proactive roles in the strategy determination process (Wright \& Snell, 1998). In this case, HR managers assume important responsibilities both in the formation and implementation of strategies.

The application and strategies developed by human resources departments to support the strategic plans and implementations of the enterprise depend on internal and external compliance criteria (Wright \& Snell, 1998). According to this; each HR application in the company should be compatible with another HR application. In other words, one HR application in the enterprise should not reduce or eliminate the impact of the other HR application. External compliance is the compliance of HRM practices and systems with all organizational objectives and strategies (Truss \& Gratton, 1994). External compliance is based on the contingency approach from management theories. According to the contingency approach, the success of HRM strategies depends on the adaptation and implementation of business strategies (Delery \& Doty, 1996).

\section{Developing the Conceptual Model}

In the literature review, EM, SCM and HRM applications are explained separately and the concepts that will form the basis of the model are examined. In the model, EM and SCM dimensions were used for GSCM integration and EM and HRM dimensions were used as the basis for GHRM integration. In the next part of the study, the effects of GSCM and GHRM on environmental performance separately and the contribution of GSCM and GHRM as a result of their interactions (GSCM * GHRM) will be discussed. In the model, the environmental performance of the companies is considered within the framework of the concept of sustainability. An integrated conceptual model

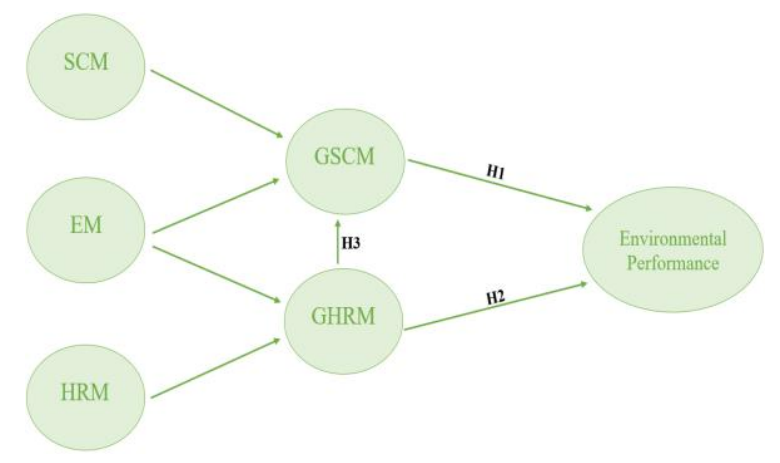

Figure 1. Proposed Conceptual Model (GSCM, GHRM and Environmental Performance Relationships)

Relations between SCM, EM, HRM dimensions and environmental performance of firms, GSCM relationships formed by EM and SCM and GHRM relationships formed by EM and HRM dimensions are shown in Figure 1. The multiplicative relationship and additive relationship between variables in the model can be formulated as follows.

F1 $\quad$ GSCM Performance $=f(\mathrm{SCM}+\mathrm{EM})$.

F2 $\quad$ GHRM Performance $=f(\mathrm{HRM}+\mathrm{EM})$.

F3 Environmental Performance $=f(\mathrm{GSCM}+\mathrm{GHRM})$.

F4 Environmental Performance $=f(\mathrm{GSCM} \times \mathrm{GHRM})$. 
According to Formula 1, SCM and EM independently affect GSCM performance. The relationships between SCM and EM are not multiplicative. Similarly, in Formula 2, the relationships between HRM and EM are not multiplicative. HRM and EM independently have effects on GHRM. The main question of the study is the relationship between GSCM and GHRM is shown in Formulas 3 and 4. According to Formula 3, GSCM and GHRM independently affect the environmental performance of firms. The fact that one is zero does not eliminate the effect of other factors. The relationship in this formula is additive, not multiplicative.

\subsection{Green Supply Chain Management}

Due to increasing carbon emissions and climate change in recent years, environmental protection initiatives are being considered globally. Green Supply Chain Management is one of the largest initiatives initiated by the industrial sector to minimize the negative environmental impacts of value chain activities (Zhu, Sarkis \& Geng, 2005).

While sustainable supply chain management activities focus on all three of the economic, social and environmental performance indicators, GSCM is a subsystem of sustainable SCM (Brandenburg, Govindan, Sarkis \& Seuring, 2014; Seuring \& Müller, 2008).

GSCM expresses the long-term cooperation aimed at minimizing the environmental impacts of the activities of the companies and reducing the negative effects of the activities of all companies on the chain. In short, the concept of GSCM is the greening of all phases of the supply chain against the environment (Ageron, Gunasekaran \& Spalanzani, 2012). However, the efforts of the companies in the chain to cooperate in all processes require high trust and long-term relationships. The essence of supply chain management; cooperation is based on buyer-supplier relations (Vickery, Jayaram, Droge \& Calantone, 2003).

Handfield, Walton, Seegers and Melnyk (1997), focus on the interactions between the supplier and the buyer to improve the environmental performance of the buyer. Gavaghan, CalahanKlein, Olson \& Pritchett (1998), in their study, focused on buyer-supplier cooperation in order to improve the environmental performance of suppliers. Vachon \& Robert (2006), emphasized that buyer companies gather information to evaluate and control the supplier's environmental performance.

Green supply chain management consists of many sub-processes. These; green product design, green material management / manufacturing, green distribution / marketing and reverse logistics (Ghobakhloo et al., 2013). Green product design is an effective process in supplier selection.

Among the other factors, green management approaches are taken into consideration when selecting suppliers. Green production/material management is the process of making environment-friendly requirements during production. Green distribution is an important factor affecting the green supply chain. Many factors, from the fuel used by the vehicle to the frequency of transportation, affect green distribution performance.

However, determination of distribution points, determination of transport type to be used, control systems, just-in-time production and distribution policies affect both forward and reverse logistics networks (Büyüközkan \& Vardaloğlu, 2008). GSCM applications can be classified as more internal and external. Internal environmental management, eco-design and investment recovery activities are classified under the Internal GSCM title. Green procurement and cooperation with customers are grouped as External GSCM (Zhu, Sarkis \& Lai, 2008). 
Table 2: Green Supply Chain Management

\begin{tabular}{|c|c|}
\hline \multirow{6}{*}{$\begin{array}{c}\text { Internal GSCM } \\
\text { (Green Production) }\end{array}$} & Evaluate materials and energy consumption and consider efficiency. \\
\hline & $\begin{array}{l}\text { Designing products that can be reused, recycled; parts and materials that can be } \\
\text { recovered. }\end{array}$ \\
\hline & Product design without hazardous substances. \\
\hline & Use of a minimum variety of materials and components in product production. \\
\hline & Reducing the use of raw materials as much as possible. \\
\hline & Reduction of toxic substance consumption. \\
\hline \multirow[t]{6}{*}{ External GSCM } & Audit of suppliers in terms of environmental performance. \\
\hline & Selection of suppliers according to environmental criteria. \\
\hline & Collaborate with suppliers on environmental management. \\
\hline & $\begin{array}{l}\text { Having the rules and requirements related to environmental management in the } \\
\text { purchasing conditions. }\end{array}$ \\
\hline & Develop suppliers to meet environmental requirements. \\
\hline & Cooperating with suppliers for green design purposes. \\
\hline
\end{tabular}

From this point of view, our first hypothesis is given as the GSCM's dimensions constitute an important resource for the organization and contribute to the environmental performance and competitive advantage of the organization.

Hypothesis 1: There is a significant and positive relationship between GSCM applications and the environmental performance of the company.

Hypothesis 1a: There is a significant and positive relationship between internal GSCM applications and the environmental performance of the company.

Hypothesis 1b: There is a significant and positive relationship between external GSCM applications and the environmental performance of the company.

\subsection{Green Human Resource Management}

Organizational structure and processes are of great importance in the development of environmentally friendly features of organizations.

Organizational determinants have strong effects on distinguishing firms from their competitors with their environmental performance as they are in the internal structure of the organization and they are features that make the organization different from other organizations.

Bruntland Report (1987), Stockholm conference (1972), Rio de Janerio (1992) conference, EcoManagement and Audit Scheme (EMAS), BS 7750 Environmental Management Standard, ISO 14000 Environmental Management System Standards Series formulated by International Standards Organization (ISO), Kyoto Protocol (1997) and Paris Agreement (2015) are important initiatives for environmental protection in the world. All these developments have led to changes in management understanding and business conduct in national and international companies. 
Enterprises have implemented their environmental systems appropriate to their business structures and the green management approach has become widespread (Chan, 2011; Deshwal, 2015; Jabbour \& Santos, 2008). One of the other important developments is the issues related to the environmental and social impacts of the enterprises have gained a strategic character discussed in the high-level board meetings. Green management practices, which express that companies operate with a sense of environmental responsibility, have influenced the functioning of all business functions. In companies with a high level of environmental awareness and sensitivity in top management, this understanding has been realized faster (Dai, Montaabon \& Cantor, 2014). Purchasing, production, distribution, marketing, research and development, accounting and finance, human resources, public relations, etc. all unit managers are expected to behave by the green management approach. Rani and Mishra (2014), states human resources departments in institutions can play an important role in the development and implementation of sustainability strategies. While the work on GHRM is still very recent, firms can revise or redesign their GHRM systems, taking into account environmental elements and the enterprise's environmental strategies in each of their traditional HRM practices (selection, training, rewarding and promotion, etc.). Green HRM implementation proposals that can be applied in HRM systems and processes are summarized in Table 3 below.

Table 3: Green Human Resources Management

\begin{tabular}{|c|c|}
\hline \multirow[t]{5}{*}{$\begin{array}{l}\text { Green selection } \\
\text { and placement }\end{array}$} & $\begin{array}{l}\text { Using environmental criteria in the selection and placement process, prioritizing } \\
\text { the candidate's prior work experience in environmental management and } \\
\text { environmental awareness (Daily \& Huan, 2001). }\end{array}$ \\
\hline & $\begin{array}{l}\text { Entrepreneurial attractiveness through environmental management and eco-friendly } \\
\text { practices and the active role of HRM departments in creating brand identity, } \\
\text { managing the perception of being the workplace that talents prefer to work with } \\
\text { developed projects (Jabbour \& Santos, 2008). }\end{array}$ \\
\hline & $\begin{array}{l}\text { Written environmental responsibilities in job descriptions (Jabbour \& Santos, } \\
\text { 2008). }\end{array}$ \\
\hline & $\begin{array}{l}\text { In the recruitment process, the company and HRM departments use environmental } \\
\text { selection and placement techniques, e-recruitment practices (Jabbour \& Santos, } \\
\text { 2008; Daily \& Huang, 2001). }\end{array}$ \\
\hline & $\begin{array}{l}\text { Orientation training and practices related to environmental management and } \\
\text { environmental sensitivities of the company in the socialization processes of new } \\
\text { employees. }\end{array}$ \\
\hline \multirow[t]{3}{*}{$\begin{array}{c}\text { Green training and } \\
\text { development }\end{array}$} & $\begin{array}{l}\text { Providing environmental education to employees for awareness, talent, expertise } \\
\text { and attitude change (Daily, Bishop\& Massoud, 2012). }\end{array}$ \\
\hline & $\begin{array}{l}\text { Workshops that bring together competent employees in green management and } \\
\text { others. }\end{array}$ \\
\hline & To gain a green manager style and attitudes. \\
\hline
\end{tabular}




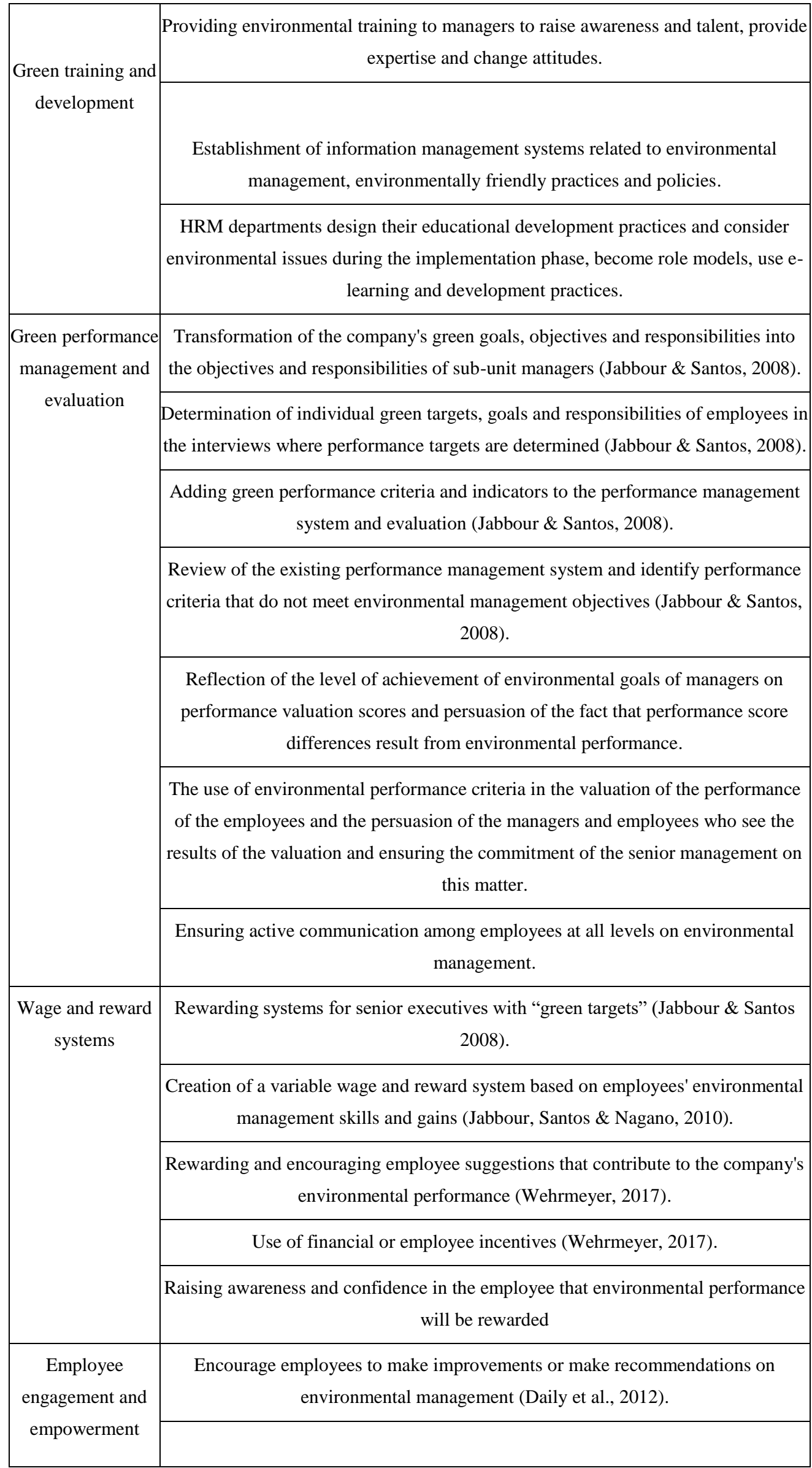




\begin{tabular}{|c|c|}
\hline $\begin{array}{c}\text { Employee } \\
\text { engagement and } \\
\text { empowerment }\end{array}$ & $\begin{array}{c}\text { Psychological empowerment and motivation of employees in environmental } \\
\text { management (Daily et al., 2012). }\end{array}$ \\
\cline { 2 - 3 } & $\begin{array}{c}\text { Executive behaviors that support and motivate employee participation in } \\
\text { environmental management. }\end{array}$ \\
\cline { 2 - 3 } $\begin{array}{c}\text { Employee } \\
\text { discipline }\end{array}$ & $\begin{array}{c}\text { Linking to the rules and regulations of employee behavior to protect the } \\
\text { environment in line with the company's environmental policy, disclosure of } \\
\text { sanctions in case of violation of rules and regulations (Hosain \& Rahman 2016; } \\
\text { Wehrmeyer, 2017). }\end{array}$ \\
\hline $\begin{array}{c}\text { Organizational } \\
\text { culture and } \\
\text { organizational } \\
\text { climate }\end{array}$ & $\begin{array}{c}\text { To support an environmentally friendly (green) culture in environmental } \\
\text { management. }\end{array}$ \\
\cline { 2 - 2 } & $\begin{array}{c}\text { Provide views and suggestions on staff at senior management meetings to make } \\
\text { senior management's support for green organizational culture visible to employees } \\
\text { (Jabbour \& Santos 2008). }\end{array}$ \\
\hline
\end{tabular}

The principles and values of environmental management can be transformed into GHRM applications together with one or more of the HRM processes. Each GHRM application (e.g. environmental education only) or a combination of different GHRM applications can contribute positively to the enterprise's environmental performance. In line with the above explanations, the second proposal is given because the dimensions of the GHRM are an important resource for the organization and may contribute to the environmental performance and competitive advantage of the organization.

Hypothesis 2: There is a significant and positive relationship between GHRM applications and the environmental performance of the company.

GSCM and GHRM independently affect the environmental performance of firms. In addition, GSCM and GHRM can also influence environmental performance by engaging in multiplicative relationships.

In this respect, our third hypothesis is given below, as the dimensions of the GHRM are an important resource for GSCM applications and contribute to the organization's environmental performance and competitive advantage through GSCM.

Hypothesis 3: GHRM applications have a mediating effect between GSCM applications and environmental performance.

Hypothesis 3a: GHRM applications have a mediating effect between internal GSCM applications and environmental performance.

Hypothesis 3b: GHRM applications have a mediating effect between external GSCM applications and environmental performance. 


\section{Research Method}

\subsection{The Purpose and Importance of Research}

The main purpose of this research is to find out how GSCM and GHRM are applied in holdings which declare that GSCM and GHRM applications are included in their companies and which are considered to be the pioneers of environmentally friendly product production and innovation in the sector. For this purpose, it has been tried to determine which practices (green raw material selection, green supplier selection, recycling, green product design, preferred type of transport, green packaging etc.) are used to improve the environmental performance of product design, material management/manufacturing, distribution/marketing and reverse logistics business processes that form SCM functions and processes of these companies.

As another aim of the research, it is tried to examine which HRM applications and systems and are integrated into GSCM systems and rate of integration in these holdings.

Also, perceptions of senior unit managers and HRM managers about which human factors are more important in the success of GSCM practices were also investigated. Another important point is that the perceptions and opinions of the senior unit managers and HRM managers about the reasons of green management application of the companies have been tried to be determined in the study.

\subsection{Data Collection Method and Sample of Research}

In the research, a focus group interview, which is one of the qualitative information gathering methods, was used. In the study, a conceptual model explaining the relationship between GHRM and GSCM is proposed based on the information collected on GHRM and GSCM. In the study, a conceptual model explaining the relationship between GHRM and GSCM is proposed based on the information collected on GHRM and GSCM. A focus group interview is one of the most commonly used methods of qualitative research. The interview method is a powerful method to reveal people's perspectives, experiences, emotions and perceptions (Bogdan \& Biklen, 1992). The focus group provides "a rich and detailed set of data about people's experiences, perceptions, thoughts, feelings and impressions of their own words" (Dilshad \& Latif, 2013).

The main body of the research is holding companies declaring that they have implemented GSCM and GHRM in Istanbul. Due to time and cost constraints, the whole population could not be reached. Judgmental sampling method, which is one of the non-probability sampling techniques, was used as the sample selection method.

The reason for the selection of holdings in the research is that they contain companies from different sectors with different levels of environmental risk such as chemistry, aluminium, construction and finance and that the attitudes of the senior executives within the holding are the most important determinant in both GHRM and GSCM applications.

Moreover, it is thought that the top managers of environmentally friendly companies will be the most knowledgeable about GHRM and GSCM, and the idea that more holistic data can be obtained from these managers has been an important motivation for focus interviews with these managers.

In addition, as the researchers report that there is a positive relationship between the scale size of the enterprise and the resources allocated by the firms for strategic human resources applications, large-scale holdings were preferred. 
Luborsky and Rubinstein (1995), argues the subject of determining sample size is controversial since there are no standard scales that define human characteristics such as cultural and social criteria in that qualitative research. A theoretical sampling approach was used in the study. In this approach, the number of samples is not determined from the beginning, data collection continues until the point where the findings of the research question can have repeated each other (Coşkun \& Bozyiğit, 2019: 614; Yıldırım \& Şimşek, 2013: 143). Therefore, the sample size was not initially determined in the study. Starting from the 23rd and 24th participants in the 12th holding, where the answers started to repeat each other, addition of new participants were terminated.

The research was carried out between 8 April 2019 - 22 May 2019. Firstly, an appointment was made for the appropriate time by calling the companies. The analysis was based on the responses of 24 participants in 12 holdings. Interviews lasted approximately 30-60 minutes and were recorded by the researcher. The recording device was not used for reasons such as lack of permission and ensuring that interviewers were sincerer and more open in the interview. The interviews were conducted with two senior executives/managers in each holding company, one of which is in HRM and the other one in charge of one of the other functions in the supply chain management. HRM managers were preferred in appointments and support was taken from the HRM manager in reaching the other managers/executives but in some companies, this process has been reversed. Interviews were conducted simultaneously with two managers in 8 companies. In 3 companies, 2 executives were interviewed in their offices on the same day in different time zones. Only one company could not make an appointment on the same day, and 2 managers were interviewed on separate days.

In the research, the managers of the units in the supply chain were asked 6 questions about green supply chain management, and the managers of the human resources department were asked 7 questions about green human resource management and its effect on green supply chain management. A semi-structured interview form was used in the study. While creating questions the studies of (Atrek \& Özdağoğlu, 2014; Coşkun \& Bozyiğit, 2019; Jabbour \& Sousa Jabbour, 2016; Longoni, Luzzini \& Guerci, 2018) were used.

In addition to these questions, the participants were also asked about non-financial reporting (i.e. GRI sustainability, integrated reporting, etc.), how many people work in the enterprise and in which sectors they have activities.

Before finalizing the research questions, as a preliminary test, opinions of 2 faculty members working in human resources management and 2 faculty members working in supply chain management were obtained for the research questions.

In addition, from 2 separate enterprises, 2 executives from human resources management and 2 executives from supply chain management were interviewed.

As a result of the feedback received from 4 academicians and 4 professionals from the sector, the interview form questions were finalized.

Descriptive and content analysis methods were used in the analysis of the research data.

Content analysis is used in qualitative research to provide systematic interpretation and analysis of the findings. Descriptive analysis, on the other hand, allows categorizing, summarizing and interpreting the data as a source (Coşkun, Altunışık, Bayraktaroğlu \& Yıldırım, 2015: 324; Coşkun \& Bozyiğit, 2019: 615). 


\subsection{Research Questions}

The research has 3 main questions. Other questions are based on these three main questions. The main questions of the research are as follows; 1 . "Why green supply chain practices matter to your company?" 2. "What kind of applications do you make in the green supply chain process?", 3. "Are there any contributions and practices of HRM departments in the green supply chain?

\subsection{Research Constraints}

The research was conducted through focus interviews with a total of 24 senior executives from 12 Holding companies. 2 executives were selected from each holding company as one from the supply chain and the other from the HRM unit. The results are limited to the data obtained through these interviews. However, this limitation arises from the purpose and questions of the research. The sample of the research consists of holding companies which perform both GSCM and GHRM activities aimed at increasing the ecological performance of SCM business processes. In other words, holdings that only implement GHRM or GHRM applications are excluded. In our country, the number of companies that implement both GSCM and GHRM applications is very limited. For example, in our country, between November 2018 and November 2019, the number of holdings that accepted to be evaluated in the sustainability index is 8 and the number of all companies is 50. Interviews were conducted with senior executives to obtain the healthiest answers for the research questions. Therefore, it is necessary to be careful about the interpretation and generalization of the results.

Secondly, only in-depth interview method, which is one of the qualitative research types, was used. As environmental HRM applications in SCM processes become widespread in the sector in the following years, quantitative methods can be used in future researches or more comprehensive data can be obtained by using qualitative and quantitative methods together.

\subsection{Validity and Reliability of the Study}

It is emphasized that a preliminary test should be conducted in order to ensure reliability in the studies conducted by using an in-depth interview method (Coşkun et al., 2015; Coşkun \& Bozyiğit, 2019: 615). A preliminary test was conducted in the research and the questions were finalized in line with the feedback received from 8 participants. The same questions were asked to the participants in the same way. All interviews were conducted by the researcher. For the study to be convincing, firstly, the analysis of the findings was explained and then the findings were interpreted.

In the study, who was interviewed, how the findings were obtained, and which analysis method was used, were explained in detail. Hence, it is thought that the study meets the reliability and validity conditions (Coşkun \& Bozyiğit, 2019: 615).

\section{Findings}

The findings section provides information about the demographic characteristics of firms and participants, and then provide answers to the questions asked by managers on HR and Supply Chain.

The research was carried out in holding companies which declared that they have applied GSCM in Istanbul. The senior managers of 12 holdings stated that they provide environmental training in their companies. 
In addition, 11 out of 12 holdings stated that they prepared GRI sustainability reports, and one stated that they used integrated reporting in which financial and non-financial data were published together. The subsidiary companies within these holdings have ISO 90001 Quality Management System certificate, ISO 14001 Environmental Management System certificate and OHSAS 18001 Occupational Health and Safety Management System certificate. The number of employees is more than 500 and they are large-scale enterprises. The subsidiary companies are active in sectors such as chemical, petroleum, plastics, paper, construction, cement, energy, logistics, automotive, tourism, food, finance and insurance.

Table 4: Title of the Participants in Companies

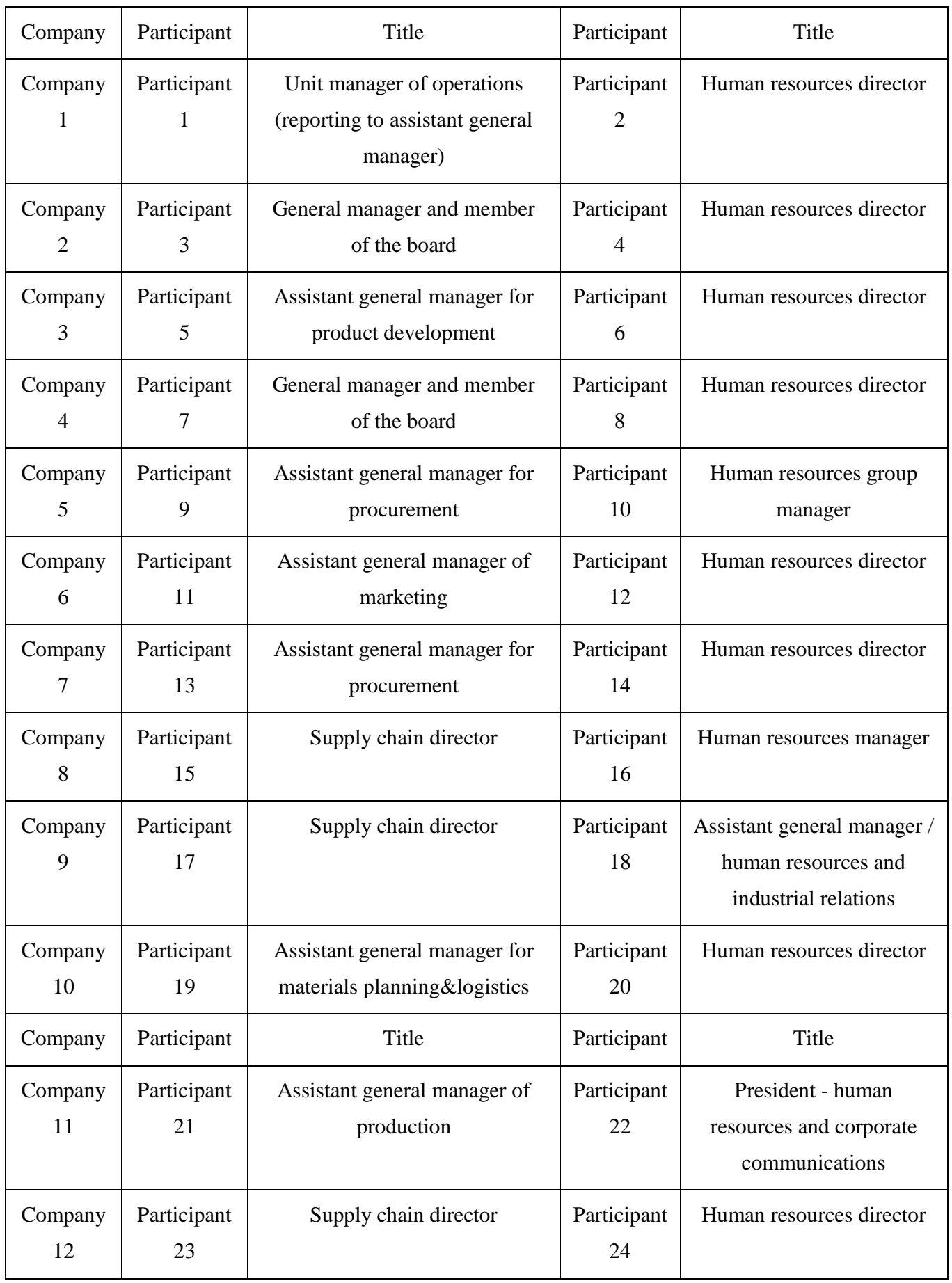


Two managers from each company were interviewed. While writing the properties of the firms; they were coded as company 1, company 2 and so on, and the participants were coded as participant 1, participant 2 and so on. For example, participant 1 is the unit manager of operations and participant 2 is the human resources director. Participant 1 and participant 2 work in the same company (company 1). In some tables, the number of answers exceeded the number of participants because the participants answered more than one question. The titles and working areas of the participants are shown in Table 4 above.

Table 5 shows the frequency and percentage values of the questions asked to human resources managers and their responses. 7 questions were asked to HR managers.

In the first question "Why does green management apply to your company?', answers were given by human resources (HR) managers as; legal obligation with $41 \%$, occupational health and safety with $24 \%$, social pressures with $24 \%$, and competition with $11 \%$.

The second question is "What are the human factors that affect the environmental performance in the green supply chain process?". In this question, answers were given by HR managers as; senior management commitment with $27 \%$, organizational culture with $23 \%$, employee involvement with $20 \%$, environmental motivation with $17 \%$, green innovation with $10 \%$ and corporate green social responsibility with $\% 3$.

Questions 3, 4, 5, 6, and 7, which were asked to HR managers in the research, are related to five HRM practices that are expected to have an impact on environmental performance in the GSCM processes. The third question is "What are your selection and placement practices to improve environmental performance in the GSCM process?". In this question, answers were given by HR managers as; using the environmental criteria with 44\%, E-recruitment with $31 \%$, orientation with $19 \%$ and create a brand identity with $6 \%$.

Table 5: Responses of HRM Managers to the Questions

\begin{tabular}{|c|c|c|c|}
\hline Question & Reply & Frequency & Percentage \\
\hline \multirow{5}{*}{$\begin{array}{c}\text { 1. Why does green management } \\
\text { apply to your company? }\end{array}$} & Legal obligation & 7 & 41 \\
\hline & Occupational health and safety & 4 & 24 \\
\hline & Social pressures & 4 & 24 \\
\hline & Competition & 2 & 11 \\
\hline & TOTAL & 17 & 100 \\
\hline \multirow{4}{*}{$\begin{array}{l}\text { 2. What are the human factors that } \\
\text { can affect the environmental } \\
\text { performance in the green supply } \\
\text { chain process? }\end{array}$} & Senior management commitment & 8 & 27 \\
\hline & Organizational culture & 7 & 23 \\
\hline & Employee involvement & 6 & 20 \\
\hline & Environmental motivation & 5 & 17 \\
\hline \multirow{3}{*}{$\begin{array}{l}\text { 2. What are the human factors that } \\
\text { can affect the environmental } \\
\text { performance in the green supply } \\
\text { chain process? }\end{array}$} & Green innovation & 3 & 10 \\
\hline & $\begin{array}{c}\text { Environmental voluntary activities of } \\
\text { employees }\end{array}$ & 1 & 3 \\
\hline & TOTAL & 30 & 100 \\
\hline
\end{tabular}




\begin{tabular}{|c|c|c|c|}
\hline \multirow{5}{*}{$\begin{array}{l}\text { 3. What are your selection and } \\
\text { placement practices to improve } \\
\text { environmental performance in the } \\
\text { GSCM process? }\end{array}$} & Using environmental criteria & 7 & 44 \\
\hline & E-recruitment & 5 & 31 \\
\hline & Orientation & 3 & 19 \\
\hline & Create a brand identity & 1 & 6 \\
\hline & TOTAL & 16 & 100 \\
\hline \multirow{6}{*}{$\begin{array}{l}\text { 4. What are your training and } \\
\text { development practices to improve } \\
\text { environmental performance in the } \\
\text { GSCM process? }\end{array}$} & $\begin{array}{c}\text { Environmental awareness and } \\
\text { consciousness training }\end{array}$ & 10 & 29 \\
\hline & E-training and development & 8 & 23 \\
\hline & Recycling training & 7 & 20 \\
\hline & Occupational health and safety & 7 & 20 \\
\hline & Environmental training for managers & 3 & 8 \\
\hline & TOTAL & 35 & 100 \\
\hline \multirow{5}{*}{$\begin{array}{l}\text { 5. What are the remuneration and } \\
\text { rewarding practices for improving } \\
\text { environmental performance in the } \\
\text { GSCM process? }\end{array}$} & Rewarding green innovations & 6 & 32 \\
\hline & Rewarding proposals and projects & 6 & 32 \\
\hline & Performance management system & 4 & 21 \\
\hline & Rewarding managers based on green targets & 3 & 15 \\
\hline & TOTAL & 19 & 100 \\
\hline \multirow{5}{*}{$\begin{array}{l}\text { 6. What are your employee } \\
\text { participation and empowerment } \\
\text { practices in order to improve } \\
\text { environmental performance in the } \\
\text { GSCM process? }\end{array}$} & Suggestion systems & 9 & 31 \\
\hline & Managerial behavior & 9 & 31 \\
\hline & Team working & 7 & 24 \\
\hline & Internal communication & 4 & 14 \\
\hline & TOTAL & 29 & 100 \\
\hline \multirow{5}{*}{$\begin{array}{l}\text { 7. What are your practices to create } \\
\text { a green organizational culture and } \\
\text { green organizational climate in } \\
\text { order to improve environmental } \\
\text { performance during the GSCM } \\
\text { process? }\end{array}$} & Managerial behavior & 10 & 33 \\
\hline & Training and development & 8 & 27 \\
\hline & Performance management & 7 & 23 \\
\hline & Green selection and placement & 5 & 17 \\
\hline & TOTAL & 30 & 100 \\
\hline
\end{tabular}

In the fourth question, "What are your training and development practices to improve the environmental performance in the GSCM process?", answers were given by HR managers as; environmental awareness and consciousness training with $29 \%$, E-training and development with $23 \%$, recycling training with $20 \%$, occupational health and safety with $20 \%$ and environmental training for managers with $8 \%$. 
In the fifth question, "What are the remuneration and rewarding practices for improving environmental performance in the GSCM process?", answers were given by HR managers as; rewarding green innovations with 32\%, rewarding proposals and projects with $32 \%$, performance management system with $21 \%$ and rewarding managers based on green targets with $15 \%$. The sixth question is "What are your employee participation and empowerment practices in order to improve environmental performance in the GSCM process?". In this question, answers were given by HR managers as suggestion systems with $31 \%$, managerial behavior with $31 \%$, and team working with $24 \%$ and internal communication with $14 \%$. The seventh question is "What are your practices to create a green organizational culture and green organizational climate in order to improve environmental performance during the GSCM process?'. In this question, answers were given by HR managers as; managerial behavior with $33 \%$, training and development with $27 \%$, performance management with $23 \%$ and green selection and placement with $17 \%$.

Table 6: Responses of SCM Managers to the Questions

\begin{tabular}{|c|c|c|c|}
\hline Question & Reply & Frequency & Percentage \\
\hline \multirow{6}{*}{$\begin{array}{l}\text { 8. Why does green management } \\
\text { apply to your company? }\end{array}$} & Total quality management & 9 & 28 \\
\hline & Legal obligation & 8 & 24 \\
\hline & Business strategy & 6 & 18 \\
\hline & Occupational health and safety & 5 & 15 \\
\hline & Environmental Awareness & 5 & 15 \\
\hline & TOTAL & 33 & 100 \\
\hline \multirow{6}{*}{$\begin{array}{l}\text { 9. What are the human factors that } \\
\text { can affect the environmental } \\
\text { performance in the supply chain } \\
\text { process? }\end{array}$} & Senior management commitment & 11 & 31 \\
\hline & Unskilled labor & 8 & 22 \\
\hline & Lack of environmental awareness & 7 & 19 \\
\hline & Lack of reward and incentives & 5 & 14 \\
\hline & Organizational culture & 5 & 14 \\
\hline & TOTAL & 36 & 100 \\
\hline \multirow[t]{5}{*}{$\begin{array}{l}10 . \text { What aspects of the } \\
\text { environment do you pay attention } \\
\text { to in your purchasing processes? }\end{array}$} & Sustainability of production & 9 & 35 \\
\hline & Raw material selection & 8 & 31 \\
\hline & Green supplier selection & 6 & 23 \\
\hline & Recycling & 3 & 11 \\
\hline & TOTAL & 26 & 100 \\
\hline & & & \\
\hline
\end{tabular}




\begin{tabular}{|c|c|c|c|}
\hline \multirow{6}{*}{$\begin{array}{l}\text { 11. What aspects of the environment } \\
\text { do you pay attention to in your } \\
\text { production processes? }\end{array}$} & Product design & 10 & 32 \\
\hline & Raw material selection & 8 & 26 \\
\hline & Total quality management & 7 & 23 \\
\hline & Recycling & 5 & 16 \\
\hline & Lean manufacturing & 1 & 3 \\
\hline & TOTAL & 31 & 100 \\
\hline \multirow{4}{*}{$\begin{array}{l}12 . \text { What practices do you have in } \\
\text { your green distribution processes? }\end{array}$} & Transportation mode & 8 & 42 \\
\hline & Green packaging & 6 & 32 \\
\hline & Reverse logistics & 5 & 26 \\
\hline & TOTAL & 19 & 100 \\
\hline \multirow{6}{*}{$\begin{array}{l}\text { 13. What activities does GHRM } \\
\text { implement in the GSCM processes? }\end{array}$} & Training and development & 10 & 32 \\
\hline & Employee involvement & 7 & 23 \\
\hline & Managing culture & 6 & 19 \\
\hline & Rewarding and incentives & 4 & 13 \\
\hline & Selection and placement & 4 & 13 \\
\hline & TOTAL & 31 & 100 \\
\hline
\end{tabular}

Table 6 shows the frequency and percentage values of the questions asked to SCM managers on the supply chain and their responses. 6 questions were asked to SCM managers in the supply chain.

The 8th question shown in Table 6 is the same as the first question asked to the HR managers in Table 5 "Why does green management apply to your company?"The 8th question is "Why does green management apply to your company?".

In this question, answers were given by supply chain (SC) managers as; total quality management with $28 \%$, legal obligation with $24 \%$, business strategy with $18 \%$, occupational health and safety with $15 \%$ and environmental awareness with $15 \%$.

Similarly, the 9th question shown in Table 6 is the same as the second question asked to the HR manager in Table 5, "What are the human factors that can affect the environmental performance in the supply chain process?"

In the 9th question, "What are the human factors that can affect the environmental performance in the supply chain process?", answers were given by SC managers as; senior management commitment with $31 \%$, unskilled labor with $22 \%$, lack of environmental awareness with $19 \%$, lack of reward and incentives with $14 \%$ and organizational culture with $14 \%$

10-11-12th questions were only asked to managers on the supply chain. The managers in this group were asked which practices they use for the protection of the environment in the procurement, production and distribution processes of the company. 
The 10th question is "What aspects of the environment do you pay attention to in your purchasing processes?”. In this question, answers were given by SC managers as; sustainability of production with $35 \%$, raw material selection with $31 \%$, green supplier selection with $23 \%$ and recycling with $11 \%$.

In the 11th question, "What aspects of the environment do you pay attention to in your production processes?", answers were given by SC managers as; product design with $32 \%$, raw material selection with $26 \%$, total quality management with $23 \%$, recycling with $16 \%$ and lean manufacturing with $3 \%$.

The 12th question is "What practices do you have in your green distribution processes?". In this question, answers were given by SC managers as; transportation mode with $42 \%$, green packaging with $32 \%$ and reverse logistics with $26 \%$.

In the 13th question, it's asked that which HRM practices are implemented for the personnel to improve the environmental performance of the company in its supply chain processes. The 13th question is "What activities does GHRM implement in the GSCM processes?"

In this question, answers were given by SC managers as; training and development with $32 \%$, employee involvement with $23 \%$, managing culture with $19 \%$, rewarding and incentives with $13 \%$ and the selection and placement with $13 \%$.

\section{Discussion}

HR managers and SC managers were divided into two groups and different questions were asked to investigate the relations between GSCM and GHRM in the study. The first two questions were jointly asked to both groups. In the first question, the managers in both groups were asked why their companies applied green management practices. With this question, it is aimed to determine and compare the opinions of both HR managers and SC managers about why green management is applied in their companies.

In the research, the answers given by the managers in the supply chain to the reasons of green management understanding in the companies were different from those of HR managers.

While managers on the supply chain express their total quality management philosophy as an important determinant of their green management approach, it is noteworthy that HR managers never mention total quality management. Another important difference is that while managers in the supply chain mention business strategies (18\%), HR managers do not. SC perceive environmental management practices as a strategic opportunity that constitutes the competitive advantage of the enterprise by $18 \%$ among their responses. SC managers are aware of the need to integrate total quality management and environmental management practices by $28 \%$ among their responses.

It is stated in the literature that the integration of TQM and EM applications will produce more synergistic results for the enterprise (Arda et al., 2018). Among the answers given by the SC managers, the reason for the green management understanding of $24 \%$ was stated as legal obligations.

Among the answers given by HR managers, the reason for the green management approach was stated as $41 \%$ legal obligation, $24 \%$ social pressures and $11 \%$ competition. 
When the answers of HRM managers are compared with the answers given by SCM managers; it is seen that HR managers perceive environmental practices in their companies at a lower rate as a means of providing strategic superiority to competitors. HR managers see environmental practices mostly as a product of institutional isomorphism (Meyer \& Rowan, 1977). However, researchers report that there is a relationship between the environmental performance and financial performance of enterprises (O'Donohue \& Torugsa, 2016).

The second common question, "What are the human factors that affect the supply chain process?" was answered the same as "senior management commitment" by both executive groups which inconsistent with the literature. Various researchers state that top management attitudes are the most important determinants of environmental performance (Daily \& Huang, 2001; Green, Zelbst, Meacham \& Bhadauria, 2012). The decisions taken regarding environmental management are the top management decisions. These activities increase costs, at least in the initial phase and they may require the company to allocate significant resources. The sensitivity of the senior management to the environment and its approach to the issue affect the environmental policies of the enterprise. The extra-role behaviors and altruism that senior management will show for environmental performance are more effective than a certificate and written policies.

Although the strategic nature of human resources management functions is frequently expressed in the literature, HR management decisions are also dependent on the commitment of senior management, the perspective of people and departments and the resources allocated to human resources practices.

Unskilled labor (22\%) and lack of environmental awareness (19\%) were important human factors affecting environmental performance among the answers given by SC managers. Inadequate performance and inaccurate decisions of the employees who have deficiencies in the knowledge and skills required by the work they perform; may lead to negative environmental consequences.

The low environmental awareness expressed by the SC managers is an important human factor that reduces the environmental performance that the researchers agree to be common in the literature. Researchers report evidence of relationships between environmental awareness and environmental behavior.

The inadequacy of reward systems (14\%) and organizational culture (14\%) was expressed as factors affecting human-related environmental performance in the supply chain.

Fewer expressions of reward systems may result from the fact that environmental behavior is not just a matter of expectation of material compensation. When people embrace environmental values, they can show altruistic environmental behaviors without rewards. However, among the answers given, $14 \%$ are expected to receive financial or honorary rewards for the environment. Among the responses of HR managers, organizational culture (23\%) was stated more important human elements than SC managers (14\%). According to Jabbour and Santos (2008), organizational culture is one of the most important elements in the implementation of the green supply chain.

Among the responses provided by HR managers, environmental voluntary activities of employees $(3 \%)$ were the least expressed human factors affecting environmental performance. This result is an unexpected remarkable finding in the study. 
The literature emphasizes the importance of the practices of voluntary environmental teams in terms of environmental performance. Kumar, Mangla, Luthra \& Ishizaka (2019), states that human factors such as organizational culture and employee participation positively affect the voluntary environmental factors of the employees in his study on human factors affecting GSCM. As an impacting factor, the GSCM environmental performance, for example, organizational culture, is a more important human factor than the voluntary environmental activities of employees. This result obtained in the study is in line with the research results of (Kumar et al., 2019).

Questions 3, 4, 5, 6, and 7, which were asked to HR managers in the research, are related to five HRM practices that are expected to have an impact on environmental performance in the GSCM processes.

HR unit managers stated that the selection and placement processes also consider environmental criteria when choosing the candidate. Renwick et al. (2013) stated that prior experience, knowledge and skills related to the environment should be taken into consideration when choosing candidates in the GHRM field. In this context, it was stated in the answers given by the HR managers that companies prefer professionals and new graduates that participate in environmental social responsibility activities. Among the answers provided by HR managers, the use of the company's environmentalist brand image as a strategy to attract talent to the business is mentioned only once. The sustainability reports that these companies publish on their web pages for information purposes, company policies regarding environmental management and voluntary social responsibility practices should not be seen as the aim of gaining legal and social acceptance.

It is recommended that these studies be turned into strategic human resources practices. In the literature, it is stated that the image of green business in recruitment processes enables talented employees to prefer business more (Guerci et al., 2016).

The transition of HRM departments to E-HRM applications causes them to redesign all HRM functions within the framework of the green management approach. Among the answers given to the research questions, it was found that the managers prefer E-recruitment in recruitment (31\%) and E-training and development (23\%) in training and development. According to these results, it can be stated that GHRM implementations have started to be adopted by HRM departments and it has started to be a role model. However, while writing job descriptions in job analysis processes, an expression that environmental responsibilities are integrated into job descriptions has not been stated by managers.

Jabbour \& Santos (2008) and Renwick et al. (2013) stated that environmental responsibilities should be included in their job descriptions. Orientation programs, on the other hand, will have beneficial results for the transfer of the importance given by top management to the subject and related policies on the environmental issues to the recruits. It is thought that orientation programs will play a major role in instilling the green values of the corporate culture to the new employees.

In the research, organizing environmental awareness training was stated as the most important factor contributing to the improvement of environmental performance in GSCM processes among the answers given by the managers. Mandip (2012) stated that training on waste management, energy efficiency and recycling should be used to improve GSCM performance. 
In the study, among the answers of the managers, it was stated that the proposals and projects(32\%) and innovations (32\%) considered to contribute to the environment after the evaluation, were awarded in the enterprise. Rewarding managers based on green targets (15\%) were the least expressed.

The frequency of using remuneration based on direct green targets in the research is 3 among HR answers' This shows that the rate of systematic integration of green practices into the wage scale is low in the companies involved in the research. However, in the researches, relationships between remuneration and environmental behaviors are found (Wehrmeyer, 2017; Jabbour et al., 2010).

When "employee participation and empowerment practices to improve environmental performance in the GSCM process" was asked, HR managers gave the most frequent answers as suggestion systems and managerial behavior ( $31 \%$ both).

Suggestion systems are one of the most effective tools that increase employee contributions and strengthen employees in environmental management (Daily et., Al. 2012). The support of suggestion systems by the company managers is very important in this process. This is because the encouragement and motivation of SC managers for employee ideas and projects is the determining factor in the implementation of the suggestion system.

In studies investigating the relationship between organizational culture and GSCM performance, organizational culture is one of the main factors affecting environmental performance (Schuler \& Jackson, 2014). It is the responsibility of employees at all levels to establish the green management approach in the enterprises (Masri \& Jaaron, 2017).

Managerial behavior was the most expressed answer with 33\% among the HR managers to the question "What are your practices to create a green organizational culture and green organizational climate in order to improve environmental performance during the GSCM process?". This result is in line with other studies in the literature (Daily \& Huang 2001).

Among the answers given by HR managers in the research, training development, performance management and selection placement practices are expressed as the practices that form the green organizational culture. Selection placement is the least expressed HRM practice among answers. However, recent researches in the literature also show that green recruitment practices in placing green values in organizational culture; It reveals that it produces more effective results than training and development practices (Masri \& Jaaron, 2017).

Questions 10,11 and 12 of the study were asked to supply chain managers. These questions were asked to determine the practices of the company for the protection of the environment in the procurement, production and distribution processes. The questions asked to the supply chain managers regarding the practices carried out for the protection of the environment in the procurement processes were answered with priority based on continuity of production. This result can be interpreted as an interesting irony of firms that shows "firstly the continuation of production then the green approach" when making the choices in the supply chain.

The applications that SC managers emphasize in purchasing; raw material selection, green supplier selection, recycling. 
In order to minimize environmental damage in production processes, the most frequently stated applications by SC managers are as follows; product design, raw material selection, total quality management, recycling and lean manufacturing.

In order to minimize environmental damage in the distribution processes, the most frequently stated applications by SC managers are as follows; transportation mode selection, green packaging and reverse logistics.

In the last question, SCM managers were asked what HRM practices the HRM department performed in supply chain processes to improve environmental performance. SC managers gave "training and development" mostly as an answer to this question. The second and third most given answers were employee involvement and organizational culture. The two least-mentioned practices were equally rewarding and incentives and selection and placement. Training and development, employee participation and empowerment, management of organizational culture are the most important applications in the effective management of ISO 90001 Quality Management and ISO 14001 Environmental Management systems (Daily and Huang, 2001; Jabbour \& Sousa Jabbour, 2016). It can be interpreted that the environmental criteria are the least implemented in the least expressed rewarding \& incentives and selection \& placement systems. Failure to add environmental criteria to selection and placement systems and fee scales will reduce HRM departments' contribution to environmental performance in GSCM applications.

\section{Conclusion}

In this study, GSCM applications of firms are classified in two ways as internal and external GSCM applications (Zhu, Sarkis \& Lai, 2008). Internal GSCM is defined as the integration of the green management approach into their systems (Zhu, Sarkis \& Lai, 2008).

It is stated that HRM policies, practices and processes developed by the HRM departments can contribute relatively more to the environmental performance of the enterprise, especially in internal GSCM practices (Kumar et al., 2019).

In the external GSCM activities, it is emphasized that all the companies in the chain are responsible for each other's activities in terms of environmental value as well as the common added value created (González, Sarkis \& Adenso-Díaz, 2008; Vickery et al., 2003). It was pointed out that each firm is in a part of value production in the process from raw material to final end-buyer, and that a single company's environmentally friendly product and innovation activities cannot have impacts at the macro level.

In the EPI 2018 report, prepared by Yale Center for Environmental Law \& Policy (Yale University) based on their environmental performance, Turkey was ranked 108th among 180 countries (The Environmental Performance Index, 2018). According to the "World Health Statistics 2018" report of the World Health Organization, Turkey was ranked 15th among the most polluted countries and it shows the importance of handling the issue within the framework of public policies and the legal regulations in this process.

Especially the demands of the EU, the importance given by foreign investors to the issue and widespread sustainability reporting or integrated reporting applications have been transforming companies to take measures in terms of environmental impacts from voluntary activities to compulsory business behaviors. 
If an enterprise continues to work with suppliers in spite of the negative business behavior socially or environmentally, the reputation of the enterprise, its brand value, its relations with investors or non-governmental organizations are also damaged (Vachon \& Robert 2006). Therefore, companies need to focus not only on their economic benefits but also on their social and environmental performance in the management of their supply chains. Each company needs to collaborate with both supplier and buyer companies in its value chain and produce joint projects in order to deal with environmental issues (Gavaghan et al., 1998). At this point, companies that want to solve the problems in external GSCM activities should create their internal GSCM systems (González et al., 2008; Vickery et al., 2003).

This study was carried out to draw attention to the positive effects of GSCM and GHRM applications on environmental performance when GSCM and GHRM applications are integrated. China and North America are the countries with the highest number of studies on the integration of SCM and EM systems. GHRM studies are a new topic that has recently been studied in the world. GHRM has also started to be implemented by companies in our country. The fact that GHRM applications in the business world are at an early stage is also reflected in the studies in the literature. There are few empirical and theoretical studies in the national literature. In this sense, the study aims to contribute to both theory and practice by trying to integrate a new issue such as GHRM into GSCM processes. In this context, a comprehensive literature review was carried out and the opinions of academicians and practitioners were taken. In the study, both a conceptual model was proposed, and qualitative research was carried out.

In the study, GSCM and GHRM dimensions were put forward and the relationships between these dimensions were examined. In the findings part of the research, the subject was discussed, and inferences were made in line with the opinions of the researchers in the literature. We believe that the study will have some important implications for academicians and practitioners working on GSCM and GHRM.

Finally, as it is seen in the findings, the most important human factor determining the environmental performance of the GSCM is determined by the senior management commitment. The size of the budget allocated by the top management of the company for environmental management and the share it gives to human resources from this budget directly affect HRM's environmental management practices. The HRM department, which receives a large amount of budget from the senior management, allocates it to its internal practices in line with the budget and implements the applications. In this respect, it can be stated that the senior management can provide support to the HRM department, which supports the GSCM processes to be environmentally sensitive and manageable, at the budget allocated by the senior management.In addition, the level of adoption of environmental values by senior management and other department managers will be decisive in the culture of the enterprise. All of these will also determine the scope and content of the HRM's systems and applications to be developed by the HRM departments. The decision choices of HRM such as the inclusion of environmental targets in wage systems, adding environmental criteria in performance management systems, preferring environmental criteria in recruitment may be possible with the support of senior management. while considering environmental factors in several HRM systems, such as training and development, employee engagement and empowerment, and managing culture. 
The lack of environmental criteria in some HRM practices, such as selection and placement, performance evaluation, remuneration and rewarding practices, will reduce HRM's contribution to GSCM environmental performance results. Unless HRM practices are considered as a whole, it is not possible to achieve the desired level of efficiency in environmental performance.

\section{Future Research Directions}

Future researchers may investigate the relationship between HRM practices and employees' innovative work behavior in environmentally friendly products and processes at the individual level. They may investigate how HRM practices affect environmental performance through increased employees' organizational citizenship behaviours toward environment. In addition, measuring the perceptions of employees and unit managers about the GHRM practices developed by HRM units can contribute to the discussions in the field.

\section{References}

Ageron, B., Gunasekaran, A. \& Spalanzani, A. (2012). Sustainable supply management: An empirical study. International Journal of Production Economics, 140(1), 168-182.

Ahi, P. \& Searcy, C. (2015). An analysis of metrics used to measure performance in green and sustainable supply chains. Journal of Cleaner Production, 86, 360-377.

Ahi, P. \&Searcy, C. (2013). A comparative literature analysis of definitions for green and sustainable supply chain management. Journal of Cleaner Production, 52, 329-341.

Akgül, U. (2010). Sürdürülebilir kalkınma: Uygulamalı antropolojinin eylem alanı. Ankara Üniversitesi Dil ve Tarih Coğrafya Fakültesi Antropoloji Dergisi, 24, 133-164.

Arda, Ö. A., Tatoğlu, E. \& Alpkan, L. (2018). Bütünleşik kalite ve çevre yönetimi uygulamaları: Kavramsal bir model önerisi. Yönetim Bilimleri Dergisi, 16(31), 11-40.

Atrek, B. \& Özdağoğlu, A. (2014). Yeşil tedarik zinciri uygulamaları: Alüminyum doğrama sektörü İzmir örneği. Anadolu University Journal of Social Sciences, 14(2), 13-26.

Baki, B. (2004) Lojistik yönetimi ve lojistik sektör analizi (1. Baskı). Trabzon: Volkan Matbaacilık.

Bogdan, R.C. \& Biklen, S.K. (1992) Qualitative research for education: An introduction to theory and methods, Boston: Allyn and Bacon.

Bowersox, D. J., Closs, D. J., Cooper, M. B. \& Bowersox, J. C. (2013). Supply chain logistics management (4th. Ed.). McGraw-Hill.

Boxall, P. \& Purcell, J. (2000). Strategic human resource management: where have we come from and where should we be going? International Journal of Management Reviews, 2(2), 183-203.

Brandenburg, M., Govindan, K., Sarkis, J. \& Seuring, S. (2014). Quantitative models for sustainable supply chain management: Developments and directions. European journal of operational research, 233(2), 299-312.

Büyüközkan, G. \& Vardaloğlu, Z. (2008). Yeşil tedarik zinciri yönetimi. Lojistik Dergisi, 8, 6673.

Chan, E. S. (2011). Implementing environmental management systems in small-and mediumsized hotels: Obstacles. Journal of Hospitality \& Tourism Research, 35(1), 3-23.

Chan, W. W. (2009). Environmental measures for hotels' environmental management systems: ISO 14001. International Journal of Contemporary Hospitality Management, 21(5), $542-560$.

Christopher, M. (1998). Logistics and supply chain management. London: Financial Times. 
Coşkun, R., Altunışık, R., Bayraktaroğlu, S. \& Yıldırım, E. (2015). Sosyal Bilimlerde Bilimsel Araştırma Yöntemleri (8. Baskı). Sakarya: Sakarya Yayıncılık.

Coşkun, S. \& Bozyiğit, S. (2019) Yeşil tedarik zinciri uygulamaları üzerine kimya sektöründe bir alan araştırması. Dokuz Eylül Üniversitesi Sosyal Bilimler Enstitüsü Dergisi, 21(2), 605-637.

Cramer, J. (1998). Environmental management: from 'fit' to 'stretch'. Business strategy and the Environment, 7(3), 162-172.

Cruz, J.M. \& Matsypura, D. (2009), Supply chain networks with corporate social responsibility through integrated environmental decision-making. International Journal of Production Research, 47(3), 621-648.

Dai, J., Montaabon, F. \& Cantor, D. (2014), Linking rival and stakeholder pressure to green supply management: mediating role of top management support, Transportation Research Part E: Logistics and Transportation Review 71(11), 173-187.

Daily, B. F. \& Huang, S. C. (2001). Achieving sustainability through attention to human resource factors in environmental management. International Journal of Operations \& Production Management, 21(12), 1539-1552.

Daily, B. F., Bishop, J. W. \& Massoud, J. A. (2012). The role of training and empowerment in environmental performance: A study of the Mexican maquiladora industry. International Journal of Operations \& Production Management, 32(5), 631-647.

Daly, H. \& Cobb, J. (1994). For the common good: Redirecting the economy toward community, the environment, and a sustainable future (No. 73). Boston, Beacon Press.

Delery, J. E. \& Doty, D. H. (1996). Modes of theorizing in strategic human resource management: Tests of universalistic, contingency, and configurational performance predictions. Academy of management Journal, 39(4), 802-835.

Deshwal, D. P. (2015). Green HRM: An organizational strategy of greening people. International Journal of Applied Research, 1(13), 176-181.

Dilshad, R. M. \& Latif, M. I. (2013). Focus group interview as a tool for qualitative research: An analysis. Pakistan Journal of Social Sciences (PJSS), 33(1), 191-198.

El-Kassar, A. N. \& Singh, S. K. (2019). Green innovation and organizational performance: the influence of big data and the moderating role of management commitment and HR practices. Technological Forecasting and Social Change, 144, 483-498.

Ellinger, A. E. \& Ellinger, A. D. (2014), Leveraging human resource development expertise to improve supply chain managers' skills and competencies, European Journal of Training and Development, 38(1/2), 118-135. https://doi.org/10.1108/EJTD-09-2013-0093.

Environmental

Performance

Index

(2018)

https://epi.envirocenter.yale.edu/downloads/epi2018policymakerssummaryv01.pdf

Epstein, M. \& Roy, M. J. (1998). Managing corporate environmental performance: A multinational perspective. European Management Journal, 16(3), 284-296.

Ganeshan, R. \& Harrison, T. P. (1995). An introduction to supply chain management. department of management science and information systems, Penn State University.

Gavaghan, K., Calahan-Klein, R., Olson, J.P. \& Pritchett, T.E., (1998). The greening of the supply chain, Supply Chain Management Review 2(2), 76-84.

Ghobakhloo, M., Tang, S. H., Zulkifli, N. \& Ariffin, M. K. A. (2013). An integrated framework of green supply chain management implementation. International Journal of Innovation, Management and Technology, 4(1), 86.

Gladwin, T. N., Kennelly, J. J. \& Krause, T. S. (1995). Shifting paradigms for sustainable development: Implications for management theory and research. Academy of management Review, 20(4), 874-907.

Global Reporting Initiative. (2006). Sürdürülebilirlik Raporlaması İlkeleri. 
Gold, S., Seuring, S. \& Beske, P. (2010). Sustainable supply chain management and interorganizational resources: a literature review. Corporate Social Responsibility and Environmental Management, 17(4), 230-245.

González, P., Sarkis, J., \& Adenso-Díaz, B. (2008). Environmental management system certification and its influence on corporate practices: Evidence from the automotive industry. International Journal of Operations \& Production Management, 28(11), 1021-1041.

Gowen III, C. R. \& Tallon, W. J. (2003). Enhancing supply chain practices through human resource management. Journal of Management Development, 22(1), 32-44.

Green Jr, K. W., Zelbst, P. J., Meacham, J. \& Bhadauria, V. S. (2012). Green supply chain management practices: Impact on performance. Supply Chain Management: $A n$ International Journal, 17(3), 290-305.

Guerci, M., Montanari, F., Scapolan, A. \& Epifanio, A. (2016). Green and nongreen recruitment practices for attracting job applicants: exploring independent and interactive effects. The International Journal of Human Resource Management, 27(2), 129-150.

Handfield, R. B., Walton, S. V., Seegers, L. K. \& Melnyk, S. A. (1997). 'Green’value chain practices in the furniture industry. Journal of Operations Management, 15(4), 293-315.

Hosain, M. D. \& Rahman, M. D. (2016). Green human resource management: A theoretical overview. IOSR Journal of Business and Management (IOSR-JBM), 18(6), 54-59.

Jabbour, C. J. C. \& De Sousa Jabbour, A. B. L. (2016). Green human resource management and green supply chain management: Linking two emerging agendas. Journal of Cleaner Production, 112, 1824-1833.

Jabbour, C. J. C. \& Santos, F. C. A. (2008). Relationships between human resource dimensions and environmental management in companies: proposal of a model. Journal of Cleaner Production, 16(1), 51-58.

Jabbour, C. J. C., Santos, F. C. A. \& Nagano, M. S. (2010). Contributions of HRM throughout the stages of environmental management: methodological triangulation applied to companies in Brazil. The International Journal of Human Resource Management, 21(7), 1049-1089

Kopicki, R., Berg, M. J. \& Legg, L. (1993). Reuse and recycling-reverse logistics opportunities. Council of Logistics Management, Oak Brook, IL.

Kumar, A., Mangla, S. K., Luthra, S. \& Ishizaka, A. (2019). Evaluating the human resource related soft dimensions in green supply chain management implementation. Production Planning \& Control, 30(9), 699-715.

Lengnick-Hall, M. L., Lengnick-Hall, C. A. \& Rigsbee, C. M. (2013). Strategic human resource management and supply chain orientation. Human Resource Management Review, 23(4), 366-377.

Longoni, A., Luzzini, D. \& Guerci, M. (2018). Deploying environmental management across functions: The relationship between green human resource management and green supply chain management. Journal of Business Ethics, 151(4), 1081-1095.

Luborsky, M. R. \& Rubinstein, R. L. (1995). Sampling in qualitative research: Rationale, issues, and methods. Research on Aging, 17(1), 89-113.

Mandip, G. (2012). Green HRM: People management commitment to environmental sustainability. Research Journal of Recent Sciences, ISSN, 2277, 2502. Vol. 1 (ISC2011), 244-252.

Masri, H. A. \& Jaaron, A. A. (2017). Assessing green human resources management practices in Palestinian manufacturing context: An empirical study. Journal of Cleaner Production, 143, 474-489.

McAfee, R. B., Glassman, M. \& Honeycutt Jr, E. D. (2002). The effects of culture and human resource management policies on supply chain management strategy. Journal of Business logistics, 23(1), 1-18. 
McMeekin, A. \& Coombs, R. (1999). Human resource management and the motivation of technical professionals. International Journal of Innovation Management, 3(01), 1-26.

Meyer, J. W. \& Rowan, B. (1977). Institutionalized organizations: Formal structure as myth and ceremony. American Journal of Sociology, 83(2), 340-363.

Miles, R. E. (1965). Human-relations or human-resources. Harvard Business Review, 43(4), $148-164$

Morrow, D. \& Rondinelli, D. (2002). Adopting corporate environmental management systems: Motivations and results of ISO 14001 and EMAS certification. European management journal, 20(2), 159-171.

Nakıboğlu, G. \& Bulgurcu, B. (2017). İşletmelerin çevresel sürdürülebilirlik göstergelerine yönelik farklı bir değerlendirme: Modifiye edilmiş dijital mantık (mdl). Uluslararası İktisadi ve İdari Incelemeler Dergisi, UİİID-IJEAS, 2017 (16. UİK Özel Sayıs1):709728 ISSN 1307-9832.

Nikbakhsh, E. (2009). Green supply chain management. In Supply Chain and Logistics in National, International and Governmental Environment. Physica-Verlag HD, 195-220.

O'Donohue, W. \& Torugsa, N. (2016). The moderating effect of "green" HRM on the association between proactive environmental management and financial performance in small firms. The International Journal of Human Resource Management, 27(2), 239261.

Polat Dede, N. (2018), İnsan kaynakları yöneticilerinin değişen rolleri ve yetkinlikleri: İlaç sektörü örneği (The changing roles and competencies of human resource managers: The example of pharma sector an application on pharma sector, İstanbul: Beta Press.

Rani, S. \& Mishra, K. (2014). Green HRM: Practices and strategic implementation in the organizations. International Journal on Recent and Innovation Trends in Computing and Communication, 2(11), 3633-3639.

Renwick, D. W., Redman, T. \& Maguire, S. (2013). Green human resource management: A review and research agenda. International Journal of Management Reviews, 15(1), 114.

Sari, K. (2017). A novel multi-criteria decision framework for evaluating green supply chain management practices. Computers \& Industrial Engineering, 105, 338-347.

Sarkis, J. (2012). A boundaries and flows perspective of green supply chain management. Supply Chain Management: An International Journal, 17(2), 202-216.

Schuler, R. \& E. Jackson, S. (2014). Human resource management and organizational effectiveness: yesterday and today. Journal of Organizational Effectiveness: People and Performance, 1(1), 35-55.

Seuring, S. \& Müller, M. (2008). From a literature review to a conceptual framework for sustainable supply chain management. Journal of cleaner production, 16(15), 16991710 .

Snell, S. A., Youndt, M. A. \& Wright, M. (1996). Establishing a framework for research in strategic human resource management: Merging resource theory and organizational learning, Research in Personnel and Human Resources Management, pp.371- 398

Srivastava, S. K. (2007). Green supply-chain management: a state-of-the-art literature review. International Journal of Management Reviews, 9(1), 53-80.

Sun, L. Y., Aryee, S. \& Law, K. S. (2007). High-performance human resource practices, citizenship behavior, and organizational performance: A relational perspective. Academy of management Journal, 50(3), 558-577.

Tatoglu, E., Frynas, J. G., Bayraktar, E., Demirbag, M., Sahadev, S., Doh, J. \& Koh, S. L. (2019). Why do emerging market firms engage in voluntary environmental management practices? A strategic choice perspective. British Journal of Management. Vol.00, pp. 1-21, DOI: 10.1111/1467-8551.12351. 
Tepedelen, F. \& Özdemir, M. (2003). ISO 14001 çevre yönetim sisteminin işletmelere sağladığ kazançlar. Sakarya University Journal of Science, 7(1), 157-162.

Thürer, M., Godinho Filho, M., Stevenson, M. \& Fredendall, L. D. (2013). Competitive priorities of small manufacturers in Brazil. Industrial Management \& Data Systems, 113(6), 856-874.

Truss, C. \& Gratton, L. (1994). Strategic human resource management: A conceptual approach. International Journal of Human Resource Management, 5(3), 663-686.

Truss, C., Gratton, L., Hope-Hailey, V., McGovern, P. \& Stiles, P. (1997). Soft and hard models of human resource management: a reappraisal. Journal of management studies, 34(1), 53-73.

Vachon, S. \& Robert D. K., (2006). Extending green practices across the supply chain: the impact of upstream and downstream integration, International Journal of Operations and Production Management, 26(7), 795-821.

Van Hoek, R. I. (1999). From reversed logistics to green supply chains. Supply Chain Management: An International Journal, 4(3), 129-135.

Vickery, S. K., Jayaram, J., Droge, C. \& Calantone, R. (2003). The effects of an integrative supply chain strategy on customer service and financial performance: an analysis of direct versus indirect relationships. Journal of Operations Management, 21(5), 523 539.

Vonderembse, M. A., Uppal, M., Huang, S. H. \& Dismukes, J. P. (2006). Designing supply chains: Towards theory development. International Journal of Production Economics $100(2), 223-238$.

Wehrmeyer, W. (2017). Greening people: Human resources and environmental management. Routledge.

Wright, P. M. \& Snell, S. A. (1998). Toward a unifying framework for exploring fit and flexibility in strategic human resource management. Academy of Management Review, 23(4), 756-772.

Yıldırım, A. \& Şimşek, H. (2013). Sosyal bilimlerde nitel araştırma yöntemleri. Ankara: Seçkin Yayıncilik.

Yüksel Ö. (1997). Örgüt kuramlarındaki gelişmelerin insan kaynakları yönetimini etkileri, Amme Ídaresi Dergisi, 30(2).

Yüksel, H. (2004). Tedarik zincirleri için performans ölçüm sistemlerinin tasarımı. Yönetim ve Ekonomi: Celal Bayar Üniversitesi İktisadi ve İdari Bilimler Fakültesi Dergisi, 11(1), 143-154.

Zaid, A. A., Bon, A. T. \& Jaaron, A. A. (2018). Green human resource management bundle practices and manufacturing organizations for performance optimization: a conceptual model. International Journal of Engineering \& Technology, 7(3.20), 87-91.

Zhu, Q., Sarkis, J. \& Geng, Y. (2005). Green supply chain management in China: pressures, practices and performance. International Journal of Operations \& Production Management, 25(5), 449-468.

Zhu, Q., Sarkis, J. \& Lai, K. H. (2008). Confirmation of a measurement model for green supply chain management practices implementation. International Journal of Production Economics, 111(2), 261-273. 